In cooperation with the Lake St. Clair Regional Monitoring Project

Estimation of Nonpoint-Source Loads of Total Nitrogen, Total Phosphorous, and Total Suspended Solids in the Black, Belle, and Pine River Basins, Michigan, by Use of the PLOAD Model

Scientific Investigations Report 2006-5071 


\section{Estimation of Nonpoint-Source Loads of Total Nitrogen, Total Phosphorous, and Total Suspended Solids in the Black, Belle, and Pine River Basins, Michigan, by Use of the PLOAD Model}

By Atiq U. Syed and Richard S. Jodoin

Scientific Investigation Report 2006-5071 


\section{U.S. Department of the Interior \\ Dirk Kempthorne, Secretary \\ U.S. Geological Survey \\ P. Patrick Leahy, Acting Director}

\section{U.S. Geological Survey, Reston, Virginia: 2006}

For more information about the USGS and its products:Telephone: 1-888-ASK-USGSWorld Wide Web: http://www.usgs.gov/

Any use of trade, product, or firm names in this publication is for descriptive purposes only and does not imply endorsement by the U.S. Government.

Although this report is in the public domain, permission must be secured from the individual copyright owners to reproduce any copyrighted materials contained within this report.

Suggested citation:

Syed, A.T., and Jodoin, R.S., 2006, Estimation of nonpoint-source loads of total nitrogen, total phosphorous, and total suspended solids in the Black, Belle, and Pine River basins, Michigan, by use of the PLOAD model: U.S. Geological Survey Scientific Investigations Report 2006-5071, 42 p. 


\section{CONTENTS}

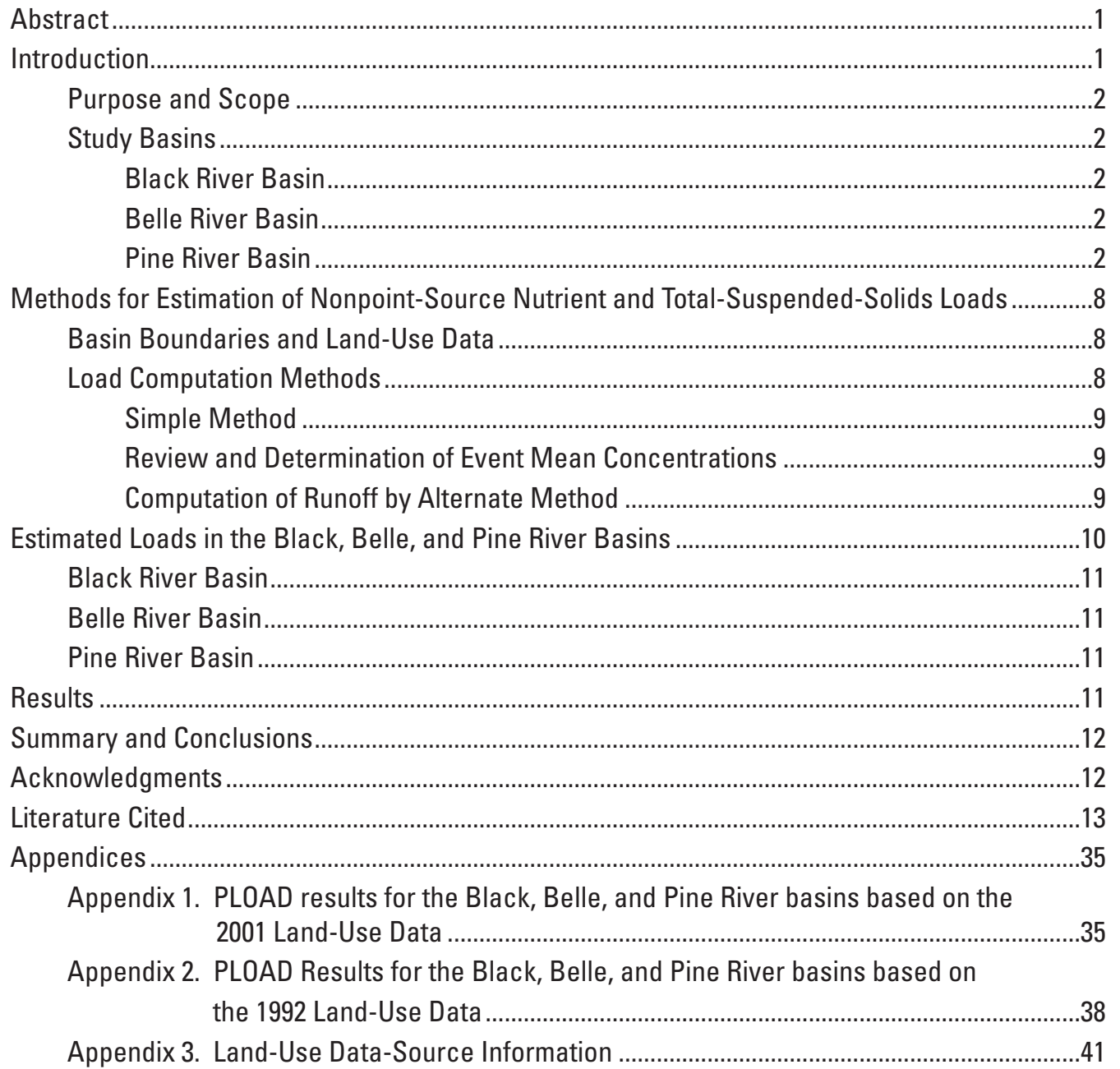

\section{FIGURES}

1. Map showing location of St. Clair and Detroit River and study basins in Michigan .....................3

2-4. Maps showing basins and subbasins:

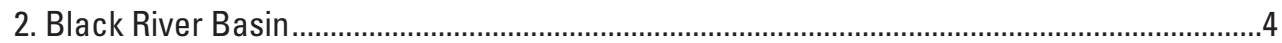

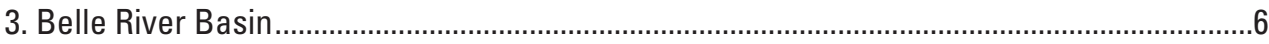

4. Pine River Basin ...............................................................................................................

5-7. Maps showing ranges of loads in the Black River Basin based on 2001 land-use data:

5. Range of total-nitrogen loads in subbasins in the Black River basin ...............................14

6. Range of total-phosphorus loads in subbasins in the Black River basin .............................15

7. Range of total-suspended-solids loads in subbasins in the Black River basin...................16

8-10. Graphs showing the distribution of loads among Black River subbasins based on the 2001 land-use data:

8. Distribution of total-nitrogen loads among Black River subbasins .....................................17

9. Distribution of total-phosphorus loads among Black River subbasins................................17 
10. Distribution of total-suspended-solids loads among Black River subbasins 17

11-13. Maps showing ranges of loads in the Belle River basin based on 2001 land-use data:

11. Range of total-nitrogen loads in subbasins in the Belle River basin .............................18

12. Range of total-phosphorus loads in subbasins in the Bell River basin ..........................19

13. Range of total-suspended-solids loads in subbasins in the Bell River basin ...............20

14-16. Graphs showing the distribution of loads among Belle River subbasins based on the 2001 land-use data:

14. Distribution of total-nitrogen loads among Belle River subbasins ...............................21

15. Distribution of total-phosphorus loads among Belle River subbasins .........................21

16. Distribution of total-suspended-solids loads among Bell River subbasins ...................21

17-19. Maps showing ranges of loads in the Pine River basin based on 2001 land-use data:

17. Range of total-nitrogen loads in subbasins in the Pine River basin ...............................22

18. Range of total-phosphorus loads in subbasins in the Pine River basin .........................23

19. Range of total-suspended-solids loads in subbasins in the Pine River basin ...............24

20-22. Graphs showing the distribution of loads among Pine River subbasins based on the 2001 land-use data:

20. Distribution of total-nitrogen loads among Pine River subbasins..................................25

21. Distribution of total-phosphorus loads among Pine River subbasins ............................25

22. Distribution of total-suspended-loads among Pine River subbasins ............................25

23-31. Maps showing normalized loads in the Black, Belle, and Pine River subbasins

23. Range of normalized total-nitrogen loads in subbasins in the Black River basin .........26

24. Range of normalized total-phosphorus loads in subbasins in the Black River basin ...27

25. Range of normalized total-suspended solids loads in subbasins in the Black River

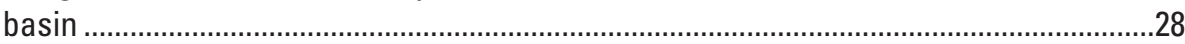

26. Range of normalized total-nitrogen loads in subbasins in the Belle River basin ..........29

27. Range of normalized total-phosphorous loads in subbasins in the Belle River basin ......................................................................................................................

28. Range of normalized total-suspended solids loads in subbasins in the Belle

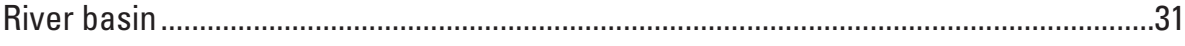

29. Range of normalized total-nitrogen loads in subbasins in the Pine River basin ...........32

30. Range of normalized total-phosphorus loads in subbasins in the Pine River

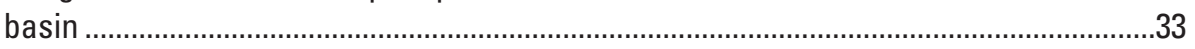

31. Range of normalized total-suspended solids loads in subbasins in the Pine River basin

\section{TABLES}

1-3. Land-use/land-cover percentages and areas, 1992 and 2001:

1. Black River basin

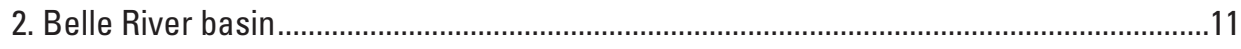

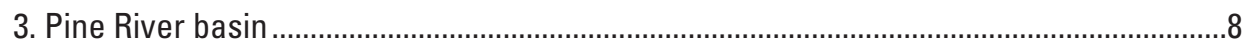

4. Percent imperviousness associated with land-use code ..............................................................

5. Event mean concentrations used in the PLOAD model to compute nutrient and total-sus-

pended-solids loading rates in the Black, Belle, and Pine River basins. 
CONVERSION FACTORS AND ABBREVIATIONS

\begin{tabular}{lcl}
\hline \multicolumn{1}{c}{ Multiply } & By & \multicolumn{1}{c}{ To obtain } \\
\hline acre & Area & \\
square mile $\left(\mathrm{mi}^{2}\right)$ & 4,047 & square meter $\left(\mathrm{m}^{2}\right)$ \\
\hline & 2.59 & square kilometer $\left(\mathrm{km}^{2}\right)$ \\
\hline mile $(\mathrm{mi})$ & Distance & \\
\hline & 1.609 & kilometer $(\mathrm{km})$ \\
\hline cubic foot per second $\left(\mathrm{ft}{ }^{3} / \mathrm{s}\right)$ & Flow rate & \\
\hline & 0.028 & cubic meter per second $\left(\mathrm{m}^{3} / \mathrm{s}\right)$ \\
\hline Pound per year $(\mathrm{lb} / \mathrm{yr})$ & Mass per unit time \\
\hline
\end{tabular}

Concentration of chemical constituents in water is given in milligrams per liter (mg/L). A milligram per liter is a unit expressing the concentration of chemical constituents in solution as weight (milligrams) of solute per unit volume (liter) of water.

The map projections are in Universal Transverse Mercator of 1983 (UTM 83), zone 17. 